\title{
Implementasi System Informasi Berbasis Web dalam Peningkatan System Pemasaran di PT. Affor Neo Jaya Makassar
}

\author{
Rahmiati $^{1}$, Baharuddin Semmaila ${ }^{2}$, Aminuddin $^{3}$ \\ ${ }^{1}$ PT. Affor Neo Jaya, Mahasiswa Magister Manajemen, Program Pascasarjana Universitas Muslim Indonesia \\ 2,3 Fakultas Ekonomi dan Bisnis, Universitas Muslim Indonesia
}

Email Korespondensi: rahmiati.makkarumba@gmail.com

\begin{abstract}
Abstrak
Tujuan penelitian ini adalah Merancang suatu system informasi pemasaran berdasarkan hasil analisis dan observasi serta Merancang system informasi pemasaran berbasis web yang dapat di akses oleh member dari PT. Affor Neo Jaya Makassar dimanapun dan kapanpun dengan leluasa. Untuk mengimplementasikan tujuan tersebut maka digunakan teknik pengumpulan data melalui observasi, dokumentasi dan penyebaran kuesioner. Analisis yang digunakan adalah analisis deskriptif kuantitatif, uji validitas dan uji reliabilitas,dan pembasan penelitian. Hasil penelitian menunjukkan bahwa 80 orang $(80,8 \%)$ sangat setuju, 16 orang $(16,1 \%)$ setuju dan 3 orang $(3,0 \%)$ kurang setuju terhadap penggunaan Aplikasi Sistem Informasi Berbasis Web. Dari hasil penelitian ini peneliti berkesimpulan bahwa penggunaan Aplikasi Sistem Informasi Berbasis Web telah berhasil meningkatkan sistem pemasaran di PT. Affor Neo Jaya Makassar.
\end{abstract}

Kata Kunci: Sistem Informasi Berbasis Web, Sistem informasi Pemasaran

\section{Pendahuluan}

Penerapan teknologi komputer khususnya dalam bidang pengolahan data telah mengalami perkembangan yang pesat. Penerapan teknologi tersebut dilakukan dengan alasan efisiensi, kenyamanan dan penghematan Sumber Daya Manusia (SDM). Perkembangan teknologi pengolahan data ini dipicu oleh daya hidup masyarakat dengan aktifitas yang padat, terutama di daerah perkotaan. Penerapan teknologi pengolahan data memungkinkan efisiensi waktu dan kemudahan akses informasi. Dengan berkembangnya teknologi internet, memungkinkan informasi dapat diperoleh melalui aplikasi. Dalam beberapa tahun terakhir ini system informasi manajemen (SIM) sangat dibutuhkan oleh perusahaan maupun organisasi system informasi manajemen (SIM) adalah salah satu dari lima subsistem utama CBIS (Computer Based Information System). Tujuannya adalah memenuhi kebutuhan informasi umum semua anggota dalam perusahaan atau dalam subunit organisasional perusahaan. Subunit dapat didasarkan pada area fungsional atau tingkatan manajemen. Semua system informasi fungsional dapat dipandang sebagai suatu system dari berbagai subsitem input, database dan output. Sistem informasi manajemen (SIM) mencerminkan suatu sikap para eksklusif yang menginginkan agar computer tersedia untuk semua pemecah masalah perusahaan.

Ketika SIM berada pada tempatnya dan berfungsi seperti yang di inginkan SIM dapat membantu admin dan pemakai lain dalam perusahaan mengidentifikasi dan memahami masalah (Mc.Leod. 2008) Salah satu subsistem dari system informasi manajemen adalah system informasi pemasaran. System informasi pemasaran (Marketing Information System) atau MKIS adalah system berbasis komputer yang bekerjasama dengan system informasi fungsional lain untuk mendukung manajemen perusahaan dalam menyelesaikan masalah yang berhubungan dengan pemasaran produk perusahaan (Mc. Leod, 2008) Sistem informasi pemasaran bisa juga diterapkan pada Lembaga keuangan seperti BMT, BPRS, Perbankan dan lain sebagainya. Sistem informasi pemasaran menggunakan system informasi berbasis web dapat memberikan informasi kepada konsumen mengenai produk yang sedang di pasarkan daftar harga produk, laporan keuangan dan data member aktif yang ada di perusahaan kosmetik PT. Affor 
Neo Jaya. Dengan adanya system pemasaran berbasis web Mereka dapat mengakses semuanya dalam satu aplikasi pemasaran. Menurut Peraturan Menteri Kesehatan RI No. 140 tahun 1991 kosmetik adalah sediaan atau paduan bahan yang siap digunakan pada bagian luar badan (epidermis, rambut, kuku, bibir, dan organ kelamin bagian luar), gigi dan rongga mulut, untuk membersihkan, menambah daya tarik, mengubah penampakan, melindungi supaya dalam keadan baik, memperbaiki bau badan, tetapi tidak dimaksud untuk mengobati atau menyembuhkan suatu penyakit. (Retno I.S. Tranggono, 1996: 29) . Keinginan untuk mempercantik diri secara berlebihan, salah pengertian akan kegunaan kosmetik, menyebabkan seseorang berbuat kesalahan dalam memilih dan menggunakan kosmetik tanpa memperhatikan kondisi kulit dan pengaruh lingkungan. Hasil yang didapatkan tidak membuat kulit menjadi sehat dan cantik, tetapi malah terjadi berbagai kelainan kulit yang disebabkan oleh penggunaan kosmetika tersebut. Gaya hidup yang kini terjadi pada masyarakat baik masyarakat kota maupun desa, tidak hanya dikalangan anak remaja tetapi juga dikalangan orang dewasa. Di zaman yang serba modern ini masyarakat dapat menemukan berbagai macam kosmetik, yang tentunya jauh lebih berkembang dibandingkan puluhan tahun lalu. Banyak menemukan variasi warna lipstick, eye shadow, blush on sampai berbagai macam mewangian parfum, sabun dan shampoo. Tidak hanya itu saja, masih banyak variasi lain yang dapat ditemui di rak-rak perusahaan kecantikan. Akan tetapi kebanyakan masyarakat membeli kosmetika tersebut tanpa mengetahui bahan - bahan atau zat - zat yang terkandung didalamnya, sehingga mereka tidak mengetahui dampak yang akan ditimbulkan. Menurut Philip kotler dalam jurnal Alexander dkk. (2009) menyatan bahwa sistem informasi pemasaran adalah suatu struktur set prosedur dan cara reguler untuk direncanakan penghimpunan, analisa, dan juga penyajian informasi untuk bisa digunakan dalam membuat keputusan pemasaran. Jadi dapat disimpulkan bahwa system Informasi Pemasaran adalah suatu sytem yang didalamnya menyajikan informasi secara prosedural dan reguler untuk merencanakan penghimpunan, analisa, dan juga penyajian informasi penjualan, promosi penjualan, aktivitas pemasaran, daftar harga produk, produk terbaru yang akan lounching dan hal lainnya berkaitan dengan pemasaran.

Pemasaran merupakan salah satu ilmu ekonomi yang telah lama berkembang, dan sampai sekarang ini pemasaran sangat mempengaruhi keberhasilan suatu perusahaan untuk bisa bertahan di dalam pangsa pasar. Oleh karena itu diperlukan strategi pemasaran yang dapat memberikan pengaruh untuk menentukan berhasil atau tidaknya dalam memasarkan produknya. Apabila strategi pemasaran yang dilaksanakan perusahaan tersebut mampumemasarkan produknya dengan baik, hal ini akan berpengaruh terhadap tujuan perusahaan. Menurut (Raharjo 2004) Web merupakan salah satu layanan internet yang paling banyak digunakan dibanding dengan layanan lain seperti ftp, gopher, news atau bahkan email. Sistem informasi berbasis web adalah seperangkat komponen yang saling berhubungan yang berfungsi untuk mengumpulkan, memproses, menyimpan dan mentransferkan informasi dalam bentuk teks, gambar, suara, dan informasi yang dipresentasikan dalam bentuk hypertext serta dapat diakses oleh perangkat lunak untuk mendukung pembuatan kegiatan dalam organisasi dalam mencapai tujuan. Perusahaan pengguna web yang dimaksud adalah "PT. Affor Neo Jaya". PT. Affor Neo Jaya sebagai salah satu perusahaan yang bergerak dalam bidang pemasaran produk kosmetik. Berdiri pada tanggal 30 Agustus 2018 dengan lounching produk pertamanya yaitu Beauty Lotion Dalam melakukan kegiatannya perusahaan ini masih menggunakan media penyampaian informasi yang sederhana, hanya dengan person to person sehingga pemasaran produk dan layanan masih belum maksimal. Pembuatan hasil laporan penjualan dan laporan daftar barang masih dilakukan dengan cara ditulis pada buku besar, yaitu dengan mencatat hasil transaksi yang diambil dari kuitansi atau nota transaksi penjualan. Data laporan hanya bersifat fisik tanpa ada backup atau data cadangan yang tersimpan di media elektronik, sehingga sering terjadi kehilangan data dan kesalahan kepenulisan. Selain itu, keterbatasan waktu untuk melayani konsumen hanya pada jam kerja saja, tetapi dengan penjualan online bisa dilakukan 24 jam per hari.

Dengan masalah yang dihadapi tersebut, maka dibutuhkan sebuah aplikasi berbasis web sebagai sistem informasinya. Hal ini sangat penting karena dengan adanya aplikasi berbasis web ini dapat membantu kendala yang ada. Customer juga akan dengan mudah mengakses informasi yang dibutuhkan kapan dan dimana saja. Dengan demikian PT Affor Neo Jaya dapat memperluas jangkauan pemasaran tanpa harus menghabiskan banyak waktu dan biaya. Selain itu juga dapat menghasilkan laporan transaksi penjualan kosmetik per hari tanpa harus mencatat padsuatu a buku besar. Dengan latar belakang diatas, menjadi dasar penulis untuk membangun suatu sistem informasi berbasis web pada PT Affor Neo Jaya. Dengan harapan dapat meningkatkan system pemasaran produk kosmetik 
yang tersedia dan mempermudah customer untuk melakukan pemasanan produk kosmetik, Berdasarkan latar belakang masalah yang telah diuraikan serta kegiatan yang dilakukan, maka masalah dapat diidentifikasi rumusan penyelesaian masalah sebagai berikut.

\section{Tabel 1. Rumusan dan Tujuan Penelitian}

\begin{tabular}{|c|l|l|}
\hline \multicolumn{2}{|c|}{ Rumusan Masalah } & \multicolumn{2}{c|}{ Tujuan Penelitian } \\
\hline 1. $\begin{array}{l}\text { Bagaimana kondisi system pemasaran sebelum } \\
\text { menggunakan sistem informasi berbasis web ? }\end{array}$ & 1. & $\begin{array}{l}\text { Merancang suatu system informasi pemasaran } \\
\text { berdasarkan hasil analisis dan observasi }\end{array}$ \\
2. $\begin{array}{l}\text { Bagaimana kondisi system pemasaran sesudah } \\
\text { menggunakan sistem informasi berbasis web ? }\end{array}$ & 2. $\begin{array}{l}\text { Merancang system informasi pemasaran } \\
\text { berbasis web yang dapat di akses oleh member } \\
\text { ANJ dimanapun dan kapanpun dengan leluasa. }\end{array}$ \\
$\begin{array}{l}\text { Bagaimana cara merancang suatu system } \\
\text { informasi berbasis web yang dapat mendukung } \\
\text { system pemasaran pada perusahaan kosmetik PT. } \\
\text { Affor Neo Jaya? }\end{array}$ & & \\
\hline
\end{tabular}

\section{Tinjauan Pustaka}

\section{A. Manajemen Pemasaran}

Pemasaran memiliki beberapa definisi menurut beberapa ahli yang dapat dipaparkan sebagai berikut: (1) Philip Kotler menyatakan pemasaran adalah kegiatan manusia yang diarahkan untuk memenuhi kebutuhan dan keinginan melalui proses pertukaran. (2) Philip Kotler dan Amstrong menyatakan pemasaran adalah sebagai suatu proses sosial dan managerial yang membuat individu dan kelompok memperoleh apa yang mereka butuhkan dan inginkan lewat penciptaan dan pertukaran timbal balik produk dan nilai dengan orang lain. (3) W Stanton mengemukakan bahwa pemasaran adalah sistem keseluruhan dari kegiatan usaha yang ditujukan untuk merencanakan, menentukan harga, mempromosikan dan mendistribusikan barang dan jasa yang dapat memuaskan kebutuhan pembeli maupun pembeli potensial. Jadi dapat disimpulkan bahwa pemasaran adalah suatu sistem total dari kegiatan bisnis yang dirancang untuk merencanakan, menentukan harga, promosi dan mendistribusikan barang- barang yang dapat memuaskan keinginan dan mencapai pasar sasaran serta tujuan perusahaan. Sistem pemasaran adalah kumpulan lembaga-lembaga yang melakukan tugas pemasaran barang, jasa, ide, orang, dan faktor-faktor lingkungan yang saling memberikan pengaruh dan membentuk serta mempengaruhi hubungan perusahaan dengan pasarnya.

Konsep-konsep inti pemasaran meluputi: kebutuhan, keinginan, permintaan, produksi, utilitas, nilai dan kepuasan; pertukaran, transaksi dan hubungan pasar, pemasaran dan pasar. Kita dapat membedakan antara kebutuhan, keinginan dan permintaan. Kebutuhan adalah suatu keadaan dirasakannya ketiadaan kepuasan dasar tertentu. Keinginan adalah kehendak yang kuat akan pemuas yang spesifik terhadap kebutuhan-kebutuhan yang lebih mendalam. Sedangkan permintaan adalah keinginan akan produk yang spesifik yang didukung dengan kemampuan dan kesediaan untuk membelinya. Proses-proses Pemasaran meliputi: menganalisa peluang pemasaran, memilih target pasar, mengembangkan marketing mix meliputi 4P (Product, Price, Place, Promotion) serta mengatur upaya pemasaran. Hal utama yang harus diperhatikan oleh sebuah perushaan saat ini agar dapat bertahan dalam persaingan bisnis global adalah harus berorientasi pada pelanggan, memenangkan pelanggan dari para pesaing dengan terlebih dahulu memahami apa yang jadi kebutuhan dan keinginannya sehingga dibutuhkan analisa pasar yang seksama. Menurut Kotler (2006) proses-proses yang dibutuhkan dalam system pemasaran meliputi: a) Segmentasi Pasar (membagi pasar kedalam kelompok pembeli yang berbeda yang memiliki perbedaan kebutuhan, karakteristik atau kebiasaan); b) Menentukan target pasar yang meliputi evaluasi terhadap tingkat kemenarikan masing-masing segmen dan memilih salah satu atau lebih segmen untuk dimasuki; c) Melakukan market positioning (Pengaturan untuk sebuah produk untuk menempati sebuah tempat yang jelas, berbeda dan diinginkan untuk bersaing dengan produk yang ada dalam pikiran konsumen; d) Management Pemasaran, manajemen pemasaran berasal dari dua kata yaitu manajemen dan pemasaran. Menurut Kotler dan Armstrong pemasaran adalah analisis, perencanaan, implementasi, dan pengendalian dari programprogram yang dirancang untuk menciptakan, membangun, dan memelihara pertukaran yang menguntungkan dengan pembeli sasaran untuk mencapai tujuan perusahaan. Sedangakan manajemen adalah proses perencanaan (Planning), pengorganisasian (organizing) penggerakan (Actuating) dan pengawasan. Jadi dapat diartikan bahwa Manajemen Pemasaran adalah sebagai analisis, perencanaan, 
penerapan, dan pengendalian program yang dirancang untuk menciptakan, membangun, dan mempertahankan pertukaran yang menguntungkan dengan pasar sasaran dengan maksud untuk mencapai tujuan - tujuan organisasi.

\section{B. Sistem informasi berbasis Web}

Pengertian sistem menurut Raymond McLeod (dalam Al-Bahra Bin Ladjamudin, 2013:3) Sistem adalah sekelompok elemen yang terintegrasi dengan maksud yang sama untuk mencapai suatu tujuan. Sedangkan menurut Gordon B. Davis (dalam Al-Bahra Bin Ladjamudin, 2013:3) Sistem sebagai bagianbagian yang saling berkaitan yang beroperasi bersama untuk mencapai beberapa sasaran atau maksud. Pengertian sistem menurut Abdul Kadir (2003:1) dalam buku Pengenalan Sistem Informasi, yaitu: "Sistem adalah sekumpulan elemen yang saling terkait atau terpadu yang dimaksudkan untuk mencapai suatu tujuan". Dari beberapa pengertian tersebut dapat diambil kesimpulan bahwa sistem merupakan kumpulan kelompok elemen yang saling berhubungan dan bekerja sama untuk mencapai suatu tujuan dan sasaran yang di inginkan.

Tata Sutabri (2012:22) Informasi adalah data yang telah diklasifikasikan atau diolah atau diinterpretasikan untuk digunakan dalam proses pengambilan keputusan. Sedangkan menurut Gordon B. Davis (dalam Al-Bahra Bin Ladjamudin, 2013:8) Informasi adalah data yang telah diolah menjadi sebuah bentuk yang berguna dan nyata atau berupa nilai yang dapat dipahami dalam keputusan sekarang maupun yang akan datang. Berdasarkan pengertian diatas dapat diambil kesimpulan bahwa Informasi adalah sebuah data yang telah diproses sehingga menjadi bentuk yang memiliki nilai yang bermanfaat. Tata Sutabri (2012:38) Sistem informasi adalah suatu sistem di dalam suatu organisasi yang mempertemukan kebutuhan pengolahan transaksi harian yang mendukung fungsi organisasi yang bersifat manajerial dalam kegiatan strategi dari suatu organisasi untuk dapat menyediakan kepada pihak luar tertentu dengan laporan - laporan yang diperlukan. Sedangkan menurut Al-Bahra Bin Ladjamudin (2013:13) mendeskripsikan Sistem informasi sebagai sekumpulan prosedur organisasi yang pada saat dilaksanakan akan memberikan informasi bagi pengambil keputusan dan atau untuk mengendalikan organisasi. Pengertian web nenurut Suwanto R. (2004) adalah Web merupakan salah satu layanan internet yang paling banyak digunakan dibanding dengan layanan lain seperti ftp, gopher, news atau bahkan email. Sedangkan pengertian HTTP menurut Aqyunin A. (2017) adalah Singkatan dari (HyperText Transfer Protocol) yaitu sebuah protokol untuk meminta dan menjawab antara client dan server. Pengertian HTML, mempunyai kepanjangan (Hyper Text Markup Language), yaitu suatu pemrograman hypertext. Html ini memiliki fungsi untuk membangun kerangka ataupun format web berbasis html. Agus Saputra (2012). Pengertian PHP, PHP atau yang memiliki kepanjangan PHP Hypertext Prepocessor, merupakan sua tu bahasa pemrograman yang difungsikan untuk membangun website dinamis. Agus Saputra (2012). Menurut Chou (1989) database adalah kumpulan informasi yang bermanfaat yang diorganisasikan ke dalam tatacara yang khusus. Menurut fabbri dan Schwab, database adalah system berkas terpadu yang dirancang terutama untuk meminimalkan pengulangan (redundancy) data. MySQL bukan termasuk bahasa pemrograman. MySQL merupakan salah satu database populer dan mendunia. Agus Saputra (2012).

Sistem informasi berbasis web adalah seperangkat komponen yang saling berhubungan yang berfungsi untuk mengumpulkan, memproses, menyimpan dan mentransferkan informasi dalam bentuk teks, gambar, suara, dan informasi yang dipresentasikan dalam bentuk hypertext serta dapat diakses oleh perangkat lunak untuk mendukung pembuatan kegiatan dalam organisasi dalam mencapai tujuan. Untuk menterjemahkan dokumen hypertext kedalam bentuk dokumen yang dapat dipahami oleh manusia, maka web browser melalui web client akan membaca halaman web yang tersimpan di sebuah webserver melalui protocol yang sering disebut dengan HTTP (Hypertext Transfer Protocol). PHP merupakan singkatan dari Hypertext Prepocessor yaitu sebuah bahasa scripting yang terpasang pada HTML dengan tujuan digunakan secara luas untuk penanganan pembuatan dan pengembangan sebuah web. PHP ditulis dan diperkenalkan pertama kali sekitar tahun 1994 oleh Rasmus Lerdorf melalui situsnya untuk mengetahui siapa saja yang telah mengakses ringkasan onlinenya. Kelebihan Sistem Informasi Berbasis Web: 1) Kita dapat menjalankan aplikasi berbasis web dimanapun kapanpun tanpa harus melakukan penginstalan; 2) Terkait dengan isu lisensi (hak cipta), kita tidak memerlukan lisensi ketika menggunakan web-based application, sebab lisensi telah menjadi tanggung jawab dari web penyedia aplikasi; 3) Dapat dijalankan di system operasi manapun. Tidak perduli apakah kita menggunakan linux, windows, aplikasi berbasis web dapat dijalankan asalkan kita 
memiliki browser dan akses internet; 4) Dapat diakses lewat banyak media seperti: computer, handheld dan handphone yang sudah sesuai dengan standard WAP. Tidak perlu spesifikasi computer yang tingggi untuk menggunakan aplikasi berbasis web ini, sebab di beberapa kasus, sebagian besar proses dilakukan di web server penyedia aplikasi berbasis web ini. Adapun kelemahan Sistem Informasi Berbasis Web yaitu: a) dibutuhkan koneksi intranet dan internet yang handal dan stabil, hal ini bertujuan agar pada saat aplikasi dijalankan akan berjalan dengan baik dan lancer; $b$ ) ibutuhkan system keamanan yang baik dikarenakan aplikasi dijalankan secara terpusat, sehingga apabila server di pusat down maka system aplikasi tidak bias berjalan.

Dalam pembangunan aplikasi aplikasi berbasis web ini penulis menggunakan (a) metode prototype. Prototype model adalah salah satu metode pengembangan perangkat lunak yang banyak digunakan. Dengan metode prototyping ini pengembangan dan pelanggan dapat saling berinteraksi selama proses pembuatan sistem. Sering terjadi seorang pelanggan hanya mendefinisikan secara umum apa yang dibutuhkan, Pemrosesan dan data-data apa saja yang dibutuhkan. Sebaliknya disisi pengembang Kurang memperhatikan efesiensi algoritma. Kemampuan sistem operasi dan interface yang menghubungkan manusia dengan komputer. M. Raymond, (2001). Beberapa kelebihan Prototyping yyaitu: pengembang dapat bekerja lebih baik dalam menentukan kebutuhan pelanggan, pelanggan berperan aktif dalam pengembangan system, lebih menghemat waktu dalam pengembangan systemPenerapan menjadi lebih mudah karena pemakai mengetahui apa yang diharapkannya.

Kelemahan Prototyping yaitu: (a) Pelanggan kadang tidak melihat atau menyadari bahwa perangkat lunak yang ada belum mencantumkan kualitas perangkat lunak secara keseluruhan dan juga belum memikirkan kemampuan pemeliharaan untuk jangka waktu lama. (b) Pengembang biasanya ingin cepat menyelesaikan proyek. Sehingga menggunakan algoritma dan bahasa pemrograman yang sederhana untuk membuat prototyping lebih cepat selesai tanpa memikirkan lebih lanjut bahwa program tersebut hanya merupakan cetak biru system. (c) Hubungan pelanggan dengan komputer yang disediakan mungkin tidak mencerminkan teknik perancangan yang baik. Tahap pertama: Observasi dan mengidentifikasi kebutuhan produk yang paling mendasar. Tahap kedua: Membangun prototype dasar berdasarkan hasil observasi dan wawancara pada perusahaan kosmetik PT. Affor Neo Jaya. Tahap ketiga: Percobaan menggunakan prototype pada perusahaan kosmetik PT. Affor Neo Jaya. Tahap Keempat: Setelah melalui uji coba, observasi, implementasi system di tingkatkan kemudian di sempunakan hingga menjadi prototype lengkap. Tahap Kelima: Aplikasi prototype selesai dan siap digunakan. Aplikasi, pengertian aplikasi adalah program yang ditulis untuk melaksanakan tugas khusus dari pengguna. Jenis program ini mempunyai sifat pasti tentang pemprosesan yang harus dilakukan file data yang harus di proses guna menyelesaikan suatu pekerjaan. (Nugroho, Bunafit, 2009). Tujuan akhir dari penggunaan komputer adalah membantu pekerjaan. Karena keperluan manusia sangat beragam maka komputer dirancang untuk membantu berbagai macam aktivitas manusia. Pengertian aplikasi dalam penelitian ini adalah untuk membantu pemakai dalam melakukan proses pengolahan data transaksi dan barang masuk pada perusahaan kosmetik. Aplikasi Berbasis Web, dalam konteks ini, aplikasi berbasis web adalah praktek pelaksanaan dan pengelolaan proses bisnis utama seperti perancangan produk, pengelolaan pasokan bahan baku, manufaktur, penjualan, pemenuhan pemesanan melalui teknologi komunikasi, komputer, dan data yang telah terkomputerisasi. Aplikasi berbasis web meliputi semua hal yang harus dilakukan menggunakan teknologi informasi komunikasi (ICT) untuk melakukan kegiatan bisnis antar organisasi maupun dari organisasi ke konsumen. Penggunaan internet dari teknologi digital lainnya untuk komunikasi, koordinasi, dan manajemen organisasi.

Model Bisnis, 1) B2C (Business to Customer), dalam B2C, pelanggan secara langsung menggunakan platform internet, khususnya web, untuk melakukan aktifitas seperti browsing, ordering, dan pembayaran. Internet bukan rumah platform yang pertama menyediakan pelanggan dengan kemampuan untuk melakukan pembelian dari rumah menggunakan media telekomunikasi. Tujuan dari semua bisnis adalah untuk mampu bertahan (survive) dan memaksimalkan nilai pemilik sahamnya. Ini dapat dibuat mungkin dengan mencapai tujuan parantara (intermediate goals) yang sering disebut dengan nilai- nilai bisnis (business values). B2B (Business to Business), hubungan diantara pemasok (supplier) dan pembeli langsung (direct customer) dapat didetesiskan sebagai istilah shopping (belanja), sedangkan hubungan diantara dua entitas bisnis dapat didetesiskan sebagai procurement. Procurement dapat dilakukan dari beberapa dollar sampai jutaan dollar. Banyak individu yang terlibat dalam proses procurement, yang secara formal dan terekam. 3) B2E (Business to Environment), B2E adalah 
pengembangan dari sebagian aplikasi berbasis web. Dengan kehadiran globalisasi dan formasi nilai rantai dimana perusahaan secara bersama-sama menyediakan suatu layanan ekonomi dan tanggapan terhadap pelanggan, kebutuhan ini kemudian berkembang untuk platform yang universal yang memfasilitasi kolaborasi diantara para pekerja. Telekomunikasi telah berkembang ketika para pekerja dapat bekerja jauh dari kantor.

\section{Penelitian Terdahulu}

Penelitian terdahulu sangat penting dalam melakukan penelitian ini, karena dapat dijadika nacuan dan perbandingan secara komparatif mengenai objek penelitian sesuai dengan variabel yang diamati. Berbagai penelitian yang telah dilakukan sebelumnya, antara lain: (1) Aqyunin Amaliah (2017) tentang Implementasi Metode Prototype Dalam Membangun Aplikasi E-Business Berbasis Web pada toko usaha dagang di kabupaten Bandung" Tujuan penelitiannya adalah untuk mengetahui tingkat keberhasilan penggunaan aplikasi prototype berbasis web pada toko usaha dagang di kabupaten bandung., dan untuk menganalisa peningkatan kinerja pegawai pada toko usaha dagang di kabupaten Bandung. Hasil Penelitian menunjukkan bahwa setelah penerapan aplikasi prototype berbasis web berpengaruh positif dan signifikan terhadap system pemasaran pada toko usaha dangang di Kabupaten Bandung. (2) Fatur Rohman (2018) tentang "Implementasi system informasi berbasis web pada noni foto studio Jakarta". Tujuan penelitian tersebut adalah untuk menganalisa system informasi yang digunakan oleh Noni Foto studio serta mengukur tingkat keberhasilan penggunaan system informasi berbasis web pada noni foto studio. Dari hasil penelitian tersebut menunjukkan bahwa dengan menggunakan system informasi berbasis web maka system penjualan maupun system pemasaran took Noni Foto studio menjadi lebih mudah dan terarah. (3) Atikah (2020) tentang "Perancangan system informasi penjualan berbasis web pada PT. Andalan Dharma Mulia Tangerang" tujuan penelitian tersebut adalah untuk merancang sistem informasi penjualan yang terkomputerisasi pada PT. Andalan Darma Mulia. Dari hasil penelitian tersebut menunjukkan bahwa dengan menggunakan system informasi berbasis web maka para pembeli dapat dengan mudah mengakses daftar harga produk yang dipasarkan dan jenis- jenis produk yang di pasarkan sedangkan untuk penjual, mereka dapat mengetahui alur penjualan, mengetahuai laba dan rugi secara cepat dan akurat dan dengan mudah mennyelesaikan permasalahan pada system penjualan produk mereka.

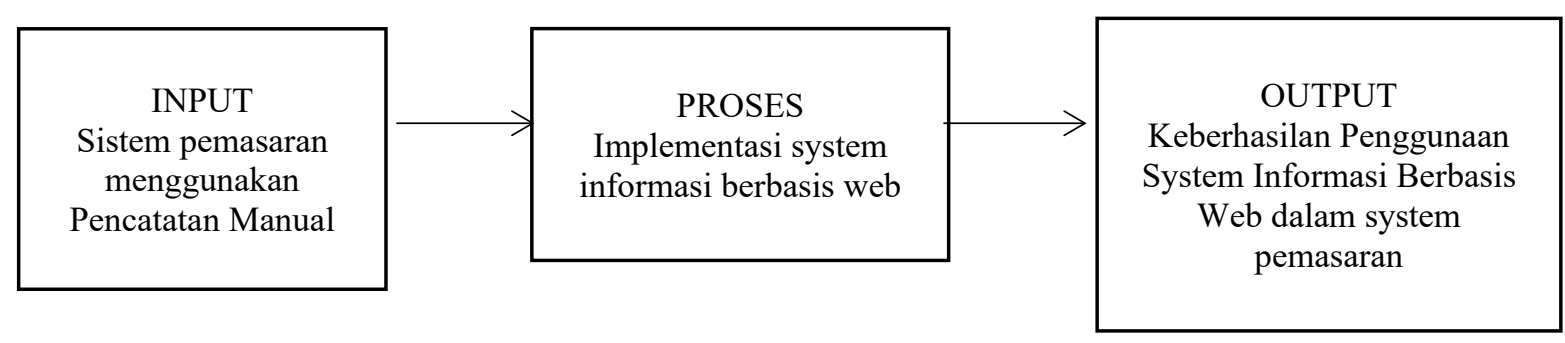

\section{Gambar 1. Kerangka Konseptual}

Berdasarkan dari kerangka di atas, peneliti berasumsi bahwa system informasi berbasis web sangat penting dalam system pemasaran karena dapat memudahkan customer dalam bertransaksi dan memudahkan dalam pelaporan keuaangan, daftar harga dan informasi barang serta transaksi pembelian disamping itu dengan adanya system informasi berbasis web member dari Pt. Affor eo Jaya dapat mengakses data pembelian maupun penjualan mereka dimana saja dan kapan saja dengan mudah dan leluasa. Berikut ini beberapa hipotesis yaitu: Diduga dengan implementasi system informasi berbasis web dapat memberikan informasi berupa laporan daftar harga dan informasi barang serta transaksi pembelian kepada konsumen. Diduga respon dari masing-masing member di PT. Affor Neo Jaya mengenai pembayaran dan informasi pengiriman lebih cepat dan tepat. Diduga dengan adanya system informasi berbasis web maka system pemasaran di PT. Affor Neo Jaya dapat diakses dengan lebih leluasa. Diduga pemasaran produk dengan menggunakan system informasi berbasis web dapat memudahkan member dalam bertransaksi 


\section{Metode Penelitian}

Dalam melakukan penelitian, perlu dikaitkan pendekatan penelitian agar penelitian yang dilakukan dapat berjalan dengan baik dan sistematis. Metode penelitian yang digunakan dalam penelitian ini adalah metode mix Kualitatif-Kuantitatif, dengan pendekatan analisis deskriptif yaitu metode yang digunakan untuk menilai respon costomer setelah penggunaan aplikasi system informasi berbasis web. dan untuk mengetahui tingkat keberhasilan penggunaan system informasi berbasis web. Data Kualitatif pada umumnya dikumpulkan melalui metode pengumpulan data, yaitu wawancara atau metode observasi, sedangkan data kuantitatif diperoleh melalui pembagian angket kepada karyawan dan staff dari PT Affor Neo Jaya. Dengan pendekatan penelitian tersebut dapat membuat gambaran secara sistematis dan akurat, mengenai fakta - fakta dan sifat - sifat, pada suatu objek penelitian tertentu. Penelitian ini dilakukan pada perusahaan PT Affor Neo Jaya dimana data yang diteliti adalah data katalog, transaksi, dan rekapitulasi data. Dalam Penyusunan Tesis ini Penulis melakukan penelitian dengan mengambil lokasi penelitian pada PT Affor Neo Jaya di Makassar. Adapun pemilihan perusahaan kosmetik ini sebagai objek penelitian dengan alasan bahwa di PT Affor Neo Jaya dalam system pemasaran dan transaksi yang berjalan masih menggunakan cara manual yaitu pencatatan yang dilakukan secara tertulis sehingga memerlukan waktu yang lama. Penelitian ini dilakukan selama sebulan yaitu bulan Juni 2021- Juli 2021. Jenis data untuk penelitian ini terdiri atas: (a) Data kuantitatif, adalah data informasi yang berupa simbol angka atau bilangan. (b) Data kualitatif adalah data yang bukan dalam bentuk angka. Seperti pedoman/petunjuk teknis (juknis), pedoman/petunjuk pelaksanaan (Juklak), peraturan perundang-undangan, serta keputusankeputusan yang berhubungan dengan kegiatan pengelolaan keuangan. Sumber data dalam penelitian ini terdiri atas: (a) Sumber Data Primer yaitu data atau segala informasi yang diperoleh dan didapat oleh penulis langsung dari sumber-sumber pertama dari individu atau sekelompok bagian dari objek penelitian. Seperti wawancara dan observasi langsung pada objek yang diteliti. (b) Sumber data sekunder yaitu data primer yang telah diolah lebih lanjut dan disajikan dengan baik, oleh pengumpul data primer atau pihak lain. Data Sekunder disajikan antara lain dalam bentuk tabel - tabel / diagram atau segala informasi yang berasal dari literatur yang ada hubungannya dengan teori - teori mengenai topik penelitian.

Menurut (Gulo 2002) pengumpulan data dilakukan untuk memperoleh informasi yang dibutuhkan untuk mencapai tujuan penelitian Dalam Penelitian ini peneliti menggunakan beberapa tehnik yaitu: (1) Observasi, pada metode ini penulis melakukan peninjauan dan pengamatan secara langsung ke lapangan untuk memperoleh dan mengumpulkan data yang dibutuhkan. Observasi dilakukan di PT. Affor Neo Jaya Makassar, Jl. Buakana VII Bua Kana, Rappocini Kota Makassar Sulawesi Selatan 90222. Pada tanggal 18 Maret s/d 18 April 2021. Berdasarkan pengamatan yang dilakukan, penulis mengumpulkan informasi mengenai: Wawancara dilakukan untuk mengetahui masalah yang berhubungan dengan system informasi pemasaran di PT. Affor Neo Jaya. Dalam wawancara ini Penulis mengambil 3 orang sampling untuk mengetahui keadaan awal member dari PT. Affor Neo Jaya yaitu:

- Owner (Nurlinda Dwi Sukti) selaku pemilik Perusahaan kosmetik.

- Admin bagian Keuangan (Syahruni Sarmin) yang mengatur alur perputaran modal dan keuntungan perusahaan

- Manager (Asnawati Nahwi) yang mengatur alur pembelian dan pemasaran produk

Metode yang penulis lakukan adalah interview bebas yaitu penulis bebas menanyakan apa saja yang relevan dengan data yang dikumpulksn. Hasil wawancara akan terlampir pada lampiran, dari hasil wawancara awal tersebut diperoleh kesimpulan bahwa :

a. Belum terdapat system yang dapat memberikan laporan periodik yang dibutuhkan oleh karyawan baik itu admin atau member dari Pt. Affor neo Jaya secara mendetail terutama dalam kegiatan pemasaran.

b. Laporan pemasaran saat ini masih bersifat manual, belum terkomputerisasi Diharapkan system yang akan dikembangkan dapat membantu para member PT Affor Neo Jaya terutama dalam kegiatan pemasaran guna menghadapi persaingan bisnis yang ada. 
Kuesioner, kuesioner yaitu proses mengumpulan data melalui pembagian angket berupa pertanyaan menyangkut system informasi berbasis web. Angket tersebut berisi tentang beberapa pertanyaan dengan tingkat penilaian Sangat Berhasil, Berhasil, Cukup Berhasil dan Kurang Berhasil. Data tersebut di analisa melalui metode persentase tingkat keberhasilan. Kuestioner akan di bagikan pada pertemuan terakhir penulis di PT. Affor Neo Jaya. Populasi dalam penelitian ini merupakan wilayah yang ingin diteliti oleh peneliti. Seperti menurut Sugiyono (2011) "Populasi adalah wilayah generalisasi yang terdiri atas obyek/subyek yang mempunyai kualitas dan karakteristik tertentu yang ditetapkan oleh peneliti untuk dipelajari dan kemudian ditarik kesimpulanya." Pendapat di atas menjadi salah satu acuan bagi penulis untuk menentukan populasi. Populasi yang akan digunakan sebagai penelitian adalah Member yang terdiri dari 13.000 orang Pada Perusahaan kosmetik PT. Affor Neo Jaya di Makassar. Sampel merupakan bagian dari populasi yang ingin di teliti oleh peneliti. Menurut Sugiyono (2011) "Sampel adalah bagian dari jumlah dan karakteristik yang dimiliki oleh populasi tersebut." Sehingga sampel merupakan bagian dari populasi yang ada, sehingga untuk pengambilan sampel harus menggunakan cara tertentu yang didasarkan oleh pertimbanganpertimbangan yang ada. Dalam teknik pengambilan sampel ini penulis menggunakan teknik Slovin menurut. Sugiyono (2011) Adapun penelitian ini menggunakan rumus Slovin dalam penarikan sampel, jumlahnya harus representative agar hasil penelitian dapat digeneralisasikan dan perhitungannya pun tidak memerlukan table jumlah sampel namun dapat dilakukan dengan rumus dan perhitungan sederhana. Rumus Slovin untuk menentukan sampel adalah sebagai berikut :

$$
n=\frac{\mathrm{N}}{1+\mathrm{N}(e)^{2}}
$$

Keterangan:

$$
\begin{aligned}
& n=\text { Ukuran sampel/jumlah sampel } \\
& \mathrm{N}=\text { Ukuran populasi } \\
& \mathrm{e}=\text { Persentase kelonggaran ketelitian kesalahan pengambilan sampel yang masih bias di tolerir ( } \\
& \mathrm{e}=10 \%)
\end{aligned}
$$

Dalam rumus Slovin ada ketentuan sebagai berikut:

Nilai $\mathrm{e}=0,1(10 \%)$ untuk populasi dalam jumlah besar

Nilai e $=0,2(20 \%)$ untuk populasi dalam jumlah kecil

Jadi rentang sampel yang dapat diambil dari tehnik Slovin adalah antara 10-20 \% dari populasi penelitian. Jumlah populasi pada penelitian ini adalah sebanyak 13.000 orang member sehingga persentase kelonggaran yang digunakan adalah $10 \%$ dan hasil perhitungannya dapat di untuk mencapai kesesuaian. Maka untuk mengetahui sampel penelitian ini dengan perhitungan sebagai berikut :

$$
\begin{gathered}
n=\frac{13.000}{1+13.000(10 \%)^{2}} \\
n=\frac{13.000}{131} \\
\mathrm{n}=99,2 \text { di sesuaikan menjadi } 99 \text { responden }
\end{gathered}
$$

Berdasarkan perhitungan diatas sampel yang menjadi responden dalam penelitian ini disesuaikan menjadi sebanyak 99 orang member atau sekitar $20 \%$ dari jumlah seluruh member di PT. Affor Noe Jaya Makassar. Hal ini dilakukan untuk mempermudah dalam pengolahan data dan untuk hasil hasil pengujian yang lebih baik.sampel ini diambil berdasarkan tehnik simple random sampling dimana peneliti memberikan peluang yang sama bagi setiap anggota populasi (member ANJ) untuk dipilih menjadi sampel yang dilakukan secara acak.

Pengumpulan data adalah proses untuk mengumpulkan data. Pada fase ini penulis mengumpulkan data berdasarkan hasil obesrvasi terhadap laporan penjualan dari PT. Affor Neo Jaya terhadap menggunakan system informasi berbasis web yang telah disiapkan oleh penulis. Dalam 
proses pengumpulan data ini penulis mengumpulkan laporan penjualan mulai dari tanggal 18 Maret s/d18 April 2021. untuk mengetahui system pemasaran selama proses penelitian berlangsung. Untuk melengkapi data, Penulis juga mewawancarai beberapa karyawan untuk mengetahui respon terhadap penggunaan system informasi berbasis web, pada PT. Affor Neo Jaya setelah aplikasi prototype tersebut di implementasikan. Seleksi Data adalah menelaah kembali hasil catatan pengamatan, hasil wawancara dan studi dokumentasi serta memisahakan data yang dianggap penting dan tidak penting. Pekerjaan ini diulang kembali untuk memeriksa keberhasilan penerapann system informasi berbasis web. setelah implementasi. Setelah data diseleksi data tersebut kemudian di reduksi berdasarkan rumusan masalah pada penelitian ini. Pada penelitian ini penulis ingin menentukan tingkat keberhasilan dari implementasi system informasi berbasis web berdasarkan pendapat dari Sugiono (2011) penulis mengumpulkan data berhubungan dengan implementasi system informasi berbasis web. Data yang telah diperoleh kemudian disajikan. Data yang disajikan tersebut harus berdasarkan atas hasil pengamatan penulis terhadap beberapa laporan penjualan kemudian mengkasifikasikan dengan memperhatikan focus dan tujuan penelitian data. Setelah tahapan diatas terpenuhi maka penulis membuat analisa akhir dalam bentuk laporan hasil penelitian. Berikut ini adalah gambar dari tahapan analasis data model "Analysis Interactive". Skala pengukuran yang digunakan oleh peneliti untuk menyatakan tanggapan dari responden terhadap setiap pertanyaan yang diberikan adalah dengan menggunakan Skala Likert. Sangat setuju (SS) : Skor 5. Setuju (S) : Skor 4. Kurang setuju (KS) : Skor 3. Tidak setuju (TS) : Skor 2. Sangat Tidak setuju (STS) : Skor 1. Uji Validitas merupakan uji yang dilakukan untuk mengukur keakuratan instrument penelitian atau angket. Angket dikatakan valid jika pertanyaan atau pernyataan dari angket tersebut mampu mengungkapka nsesuatu yang akan diukur oleh angket tersebut. Ukuran akurasi dari angket tersebut bisa diukur dengan menggunakan corrected item total correlation. Angket dikatakan bagus dan valid jika nilai corrected item total correlation $>0,30$ (Ghozali, 2016). Hasil uji validitas dilakukan menggunakan program SPSS 21. Uji reliabilitas merupakan uji angket yang dilakukan dengan maksud mengukur konsistensi jawaban responden. Uji reliabilitas dilakukan dengan uji statistik cronbach alpha. Batas ujicronbach alpha adalah $\geq 0,70$ (Ghozali, 2016). Mengunakan program SPSS 21.

\section{Pembahasan}

Responden dalam penelitian ini adalah seluruh member pada PT. Affor Neo Jaya Makassar. Peneliti mengambil jumlah responden sebanyak 99 orang yang akan dijadikan sampel dalam penelitian ini. Terdapat 4 karakteristik responden yang dimasukkan dalam penelitian ini, yaitu berdasarkan Usia, Jenis Kelamin, Penghasilan Perbulan,dan Daerah asal. Untuk memperjelas karakteristik responden yang dimaksud, maka disajikan tabel mengenai responden seperti yang dijelaskan berikut ini:

\section{A. Karakteristik Responden Berdasarkan Usia}

Tabel 2. Persentase Responden Berdasarkan Usia

\begin{tabular}{|c|c|c|c|}
\hline No. & Usia & Frekuensi (Orang) & $\mathbf{( \% )}$ \\
\hline 1. & $17-21$ Tahun & 5 & 5,05 \\
\hline 2. & $22-26$ Tahun & 21 & 21,2 \\
\hline 3. & $27-31$ Tahun & 37 & 37,3 \\
\hline 4. & $32-36$ Tahun & 26 & 26,2 \\
\hline 5 & 37 - 41 Tahun & 10 & 10,1 \\
\hline \multicolumn{2}{|l}{} & 99 & 99,85 \\
\hline
\end{tabular}

Berdasarkan dari table 2 di atas menunjukkan bahwa umur 17-21 tahun memiliki persetase responden terendah pada penelitian ini, yakni hanya 5 orang $(5,05 \%)$, kemudian disusul dengan responden usia 37- 41 tahun sebanyak 10 orang $(10,1 \%)$, responden berusia $22-26$ tahun sebanyak 21 orang $(21,2 \%)$, responden berusia $32-36$ tahun sebanyak 26 orang $(26,2 \%)$ dan yang memiliki persentase tertinggi adalah umur 27-31 tahun yakni sebanyak 37 orang (37,3\%). 


\section{B. Karakteristik Responden Berdasarkan Jenis Kelamin}

Tabel 3. Persentase Responden Berdasarkan Jenis Kelamin

\begin{tabular}{|c|c|c|c|}
\hline No. & Jenis Kelamin & $\begin{array}{c}\text { Frekuensi } \\
\text { (Orang) }\end{array}$ & $\begin{array}{c}\text { Persentase } \\
(\%)\end{array}$ \\
\hline 1. & Laki-Laki & 2 & 2,02 \\
\hline 2. & Perempuan & 97 & 97,9 \\
\hline \multicolumn{2}{|c|}{ Jumlah } & 99 & 99,92 \\
\hline
\end{tabular}

Tabel 3. menunjukkan bahwa sebagian besar responden adalah berjenis kelamin perempuan yaitu berjumlah 97 orang (97,9\%). Sedangkan laki - laki hanya berjumlah 2 orang (2,02\%) ini membuktikan bahwa dalam bisnis kosmetik ini responden yang berjenis kelamin perempuan lebih mendominasi dibandingkan responden yang berjenis kelamin laki-laki.

\section{Karakteristik Responden Berdasarkan Penghasilan Perbulan}

Tabel 4. Persentase Responden Berdasarkan Penghasilan Perbulan

\begin{tabular}{|l|l|c|c|}
\hline \multicolumn{1}{|c|}{ No } & \multicolumn{1}{|c|}{ Penghasilan Perbulan } & Frekuensi (Orang) & $\mathbf{( \% )}$ \\
\hline 1. & $500.000-2.000 .000$ & 45 & 45.4 \\
2. & $3.000 .000-5.000 .000$ & 21 & 21,2 \\
3. & $6.000 .000-10.000 .000$ & 16 & 16,1 \\
4. & $11.000 .000-20.000 .000$ & 11 & 11,1 \\
5. & $50.000 .000-100.000 .000$ & 4 & 4,04 \\
6. & $200.000 .000-300.000 .000$ & 2 & 2,02 \\
\hline & \multicolumn{2}{|r|}{ Total } & 99 \\
\hline
\end{tabular}

Tabel 4. menunjukkan sebagian besar responden berpenghasilan antara 500.000-2.000.000 sebanyak 45 orang $(45,4 \%)$ disusul responden berpenghasilan 3.000.000-5.000.000 sebanyak 21 orang (21.29\%), responden yang berpenghasilan 6.000.000-10.000.000 sebanyak 16 orang $(16,1 \%)$. Responden yang berpenghasilan 11.000.000-20.000.000 sebanyak 11 orang (11,1\%) responden yang berpenghasilan 50.000.000-100.000.000 sebanyak 4 orang (4,04\%) dan responden yang memiliki jumlah penghasilan terbanyak yaitu 200.000.000-300.000.000 adalah sebanyak 2 orang (2,02\%) ini berdasarkan tingkatan level keagenan jadi makin tinggi level keagenan member maka makin banyak juga jumlah penghasilan yang didapatkan.

\section{Karakteristik Berdasarkan Daerah Asal}

Tabel 5. Persentase Berdasarkan Daerah Asal

\begin{tabular}{|c|c|c|c|}
\hline No. & Daerah & $\begin{array}{c}\text { Frekuensi } \\
\text { (Orang) }\end{array}$ & $\begin{array}{c}\text { Persentase } \\
(\%)\end{array}$ \\
\hline 1. & Sulawesi & 10 & 10,1 \\
\hline 2. & Papua & 4 & 4,04 \\
\hline 3. & Jawa & 37 & 37,3 \\
\hline 4. & Sumatra & 28 & 28,2 \\
\hline 5. & Kalimantan & 20 & 20,2 \\
\hline \multicolumn{2}{|c|}{ Jumlah } & 99 & 99,84 \\
\hline
\end{tabular}

Tabel 5 menunjukkan bahwa umumnya penduduk yang berasal dari jawa mendominasi jumlah member dari peruhasaan kosmetik ini yaitu sebanyak 37 orang (37,3\%) disusul daerah Sumatra 28 orang $(28,2 \%)$ kemudian daerah Kalimantan sebanyak 20 orang (20,2\%) daerah Sulawesi sebanyak 10 orang $(10,1 \%)$ dan terakhir Papua sebanyak 4 orang $(4,04 \%)$ Data tersebut memperlihatkan bahwa member yang berasal dari pulau jawa memiliki respon yang sangat tinggi terhadap kosmetik sehingga penjualan terbanyak dari perusahaan kosmetik ini terletak di pulau Jawa. 


\section{Penentuan Range}

Penelitian ini menggunakan skala Likert dengan bobot tertinggi di setiap pernyataan adalah 5 dan bobot terendah adalah 1. Dengan jumlah responden sebanyak 99 orang, maka:

$$
\text { Range }=\frac{\text { Skor Tertinggi }- \text { Skor Terendah }}{\text { Range Skor }}
$$

Skor Tertinggi: $99 \times 5=495$

Skor Terendah: $99 \times 1=99$

Sehingga range untuk penelitian ini adalah:

$$
\text { Range }=\frac{495-99}{5}=79,2(\text { dibulatkan menjadi } 79)
$$

Range Skor: $20-32$ = Sangat Tidak Berhasil

$$
\begin{aligned}
& 33-49=\text { Tidak Berhasil } \\
& 50-66=\text { Kurang Berhasil } \\
& 67-83=\text { Berhasil } \\
& 84-100=\text { Sangat Berhasil }
\end{aligned}
$$

Maka dapat disimpulakn bahwa dalam penelitian ini penggunaan aplikasi berbasis web berhasil meningkatkan penjualan di PT. Affor Neo Jaya. Dalam penelitian ini akan dibahas mengenai deskripsi data masing-masing variabel penelitian yaitu Variabel Bebas $(X)$ system informasi berbasis web pada PT. Affor Neo Jaya dengan Variabel Terikat $(Y)$ yaitu sistem pemasarannya.

\section{Variabel Bebas (X) System informasi berbasis web pada PT. Affor Neo Jaya Makassar}

Analisis deskripsi tentang variabel system informasi berbasis web pada PT. Affor Neo Jaya didasarkan pada tahapan penggunaan aplikasi prototype pada Sistem Informasi Berbasis Web

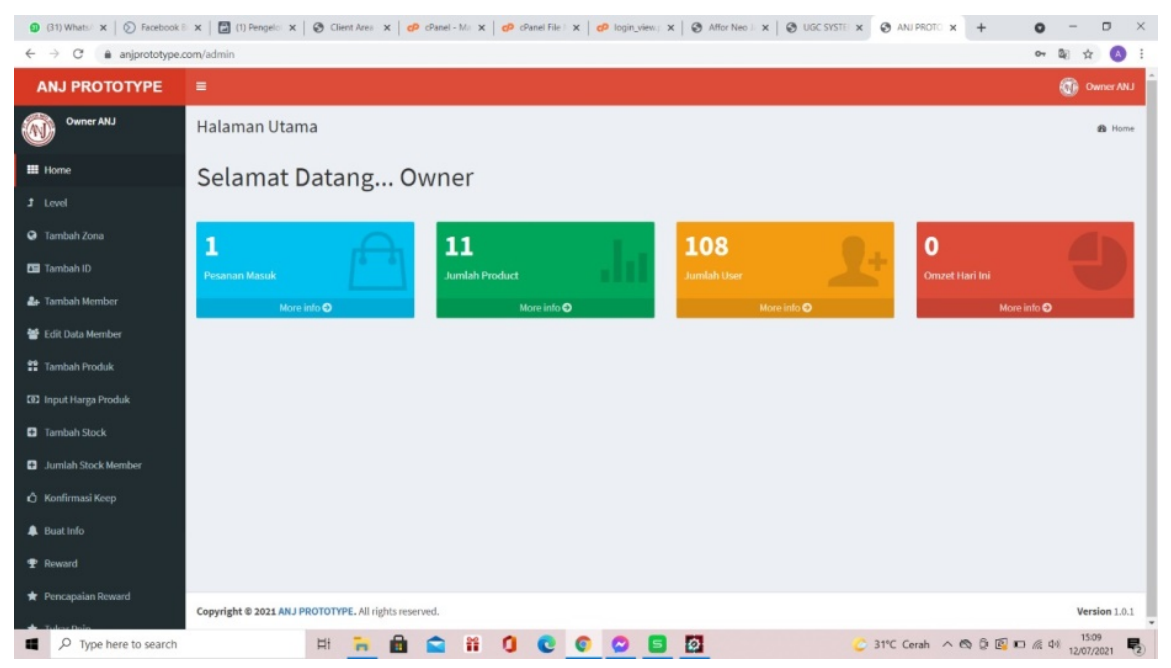

Gambar 2. Halaman Utama Aplikasi Sistem Informasi Berbasi Web

Pada halaman utama terdapat menu: Jumlah Orderan Masuk, Jumlah Produk yang tersedia, Jumlah Member, Jumlah Pemasukan Hari ini

Terdapat pula fitur-fitur pendukung seperti:

1) Level Keagenan: User dapat mengetahui jumlah member berdasarkan level keagenannya

2) Tambah Zona: User dapat menentukan harga berdasarkan alamat/zona karena setiap wilayah memiliki daftar harga produk yang berbeda 
3) Tambah ID: User dapat mambahkan member berdasarkan Nomor ID (misalkan ID 001,002,003 dan seterusnya)

4) Tambah Member: User Dapat menambah member sesuai dengan data yang valid (KTP)

5) Edit Data Member: User dapat mengedit/mengubah data member

6) Tambah Produk: User dapat menambahkan produk berdasarkan jenis produk yang tersedia

7) Imput Harga Produk: User dapat mengimput data harga produk berdasarkan daftar harga yang sudah tersedia

8) Tambah Stock: User dapat menambahkan stock sesuai dengan jumlah produk yang telah tersedia

9) Jumlah Stock Member: User dapat mengakses jumlah stock yang tersebar kepada member (downline)

10) Konfirmasi Keep: User dapat mengkonfirmasi jumlah pesanan (keep) melakukan pembatalan ataupun melakukan transaksi penjualan

11) Buat Info: User dapat membuat info baik itu barang yang tersedia (ready) atau barang telah habis (Sold Out)

12) Reward: User dapat menambahkan status hadiah (reward) kepada member yang telah mencapai target penjualan produk dengan jumlah tertentu.

13) Pencapaian Reward: User dapat memberikan info pencapaian reward bagi member yang telah mengkonfirmasi pesanan rewardnya

Berdasarkan penjelasan diatas maka penulis dapat mengetahui bahwa dengan adanya system informasi berbasi web maka member dapat dengan mudah mengakses data jumlah stok yang tersedia dan jumlah member aktif dengan cepat dan tepat, berdasarkan pernyataan admin keuangan:

"Dengan adanya aplikasi ini saya dapat mengetahui jumlah barang masuk dan keluar, dapat menghitung transaksi harian dengan cepat dan mudah, dapat mengetahui jumlah barang yang tersedia dan jumlah barang yang telah kosong" (Syahruni 3 Juli 2021)

Dengan paparan admin diatas maka dapat diketahui bahwa aplikasi system informasi berbasis web dapat membantu mengakses data lebih cepat dan lebih akurat. Lebih lanjut lagi salah satu Manager dari PT. Affor Neo Jaya mengatakan bahwa :

"Dengan adanya aplikasi ini saya dapat mengetahui jumlah turunan (downline) saya, saya juga bias mengetahui aktifitas downline saya baik itu penjualan maupun pembelian mereka, saya dapat mengetahui jumlah barang yang tersedia di kantor dan barang yang telah habis serta barang yang akan tersedia di kantor tanpa harus datang langsung ke kantor lagi"(Asnawati 3 Juli 2021)

Dengan penjelasan diatas maka penulis berkesimpulan bahwa system informasi berbasis web dapat membantu proses penjualan lebih cepat, mengetahui jumlah barang yang tersedia dengan lebih akurat, memudahkan dalam pencarian barang dan pencarian transaksi pembelian, memudahkan dalam menambahkan member dan membantu dalam pelaporan keuangan dengan lebih cepat dan akurat.

\section{Variabel Terikat (Y) Sistem Pemasaran}

Analisis deskripsi tentang variabel system pemasaran setelah penggunaan aplikasi system informasi berbasis web adalah dengan adanya aplikasi system informasi berbasis web maka pemasaran produk dari perusahaan kosmetik PT. Affor Neo Jaya menjadi lebih meningkat berikut adalah tampilan diagram persentase berdasarkan hasil dari kuesioner yaitu : 


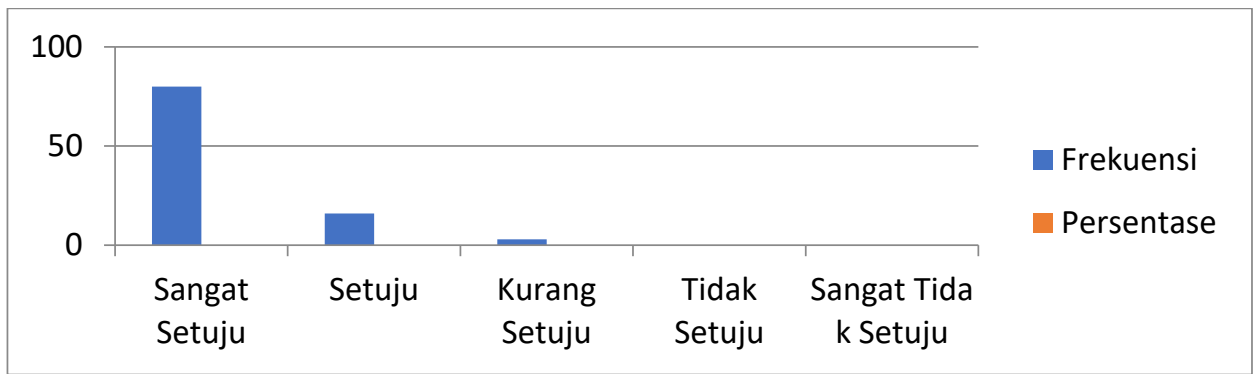

Gambar 3. Diagram hasil kuesioner

Berdasarkan diagram diatas kita dapat mengetahui bahwa 80 orang $(80,8 \%)$ menyukai menggunakan aplikasi system informasi berbasis web dengan adanya aplikasi ini maka penjualan mereka menjadi lebih meningkat dan pemasaran produk mereka menjadi lebih mudah dijangkau.

\section{Uji Validitas}

Uji validitas pada penelitian ini bertujuan untuk menguji apakah valid tidaknya suatu pernyataan/kuisioner pada penelitian. Suatu instrumen dikatakan valid apabila mampu memperoleh data yang tepat dari variabel yang diteliti. Syarat minimum untuk dianggap memenuhi syarat adalah jika $r_{\text {hitung }}>r_{\text {tabel }}(0,30)$. jika kurang dari 0,30 maka dinyatakan tidak valid. untuk selanjutnya peneliti membuat rekapitulasi hasil uji validitas seperti dalam table berikut :

Tabel 6. Hasil Uji Validitas Kuesioner System Informasi Berbasis Web

\begin{tabular}{|c|c|c|c|}
\hline Pertanyaan & R Hitung & R-Tabel & Keterangan \\
\hline Item 1 & 0,436 & 0,361 & Valid \\
\hline Item 2 & 0,447 & 0,361 & Valid \\
\hline Item 3 & 0,477 & 0,361 & Valid \\
\hline Item 4 & 0,534 & 0,361 & Valid \\
\hline Item 5 & 0,396 & 0,361 & Valid \\
\hline Item 6 & 0,423 & 0,361 & Valid \\
\hline Item 7 & 0,559 & 0,361 & Valid \\
\hline Item 8 & 0,534 & 0,361 & Valid \\
\hline Item 9 & 0,409 & 0,361 & Valid \\
\hline Item 10 & 0,362 & 0,361 & Valid \\
\hline Item 11 & 0,530 & 0,361 & Valid \\
\hline Item 12 & 0,422 & 0,361 & Valid \\
\hline Item 13 & 0,401 & 0,361 & Valid \\
\hline Item 14 & 0,397 & 0,361 & Valid \\
\hline Item 15 & 0,469 & 0,361 & Valid \\
\hline Item 16 & 0,432 & 0,361 & Valid \\
\hline Item 17 & 0,535 & 0,361 & Valid \\
\hline Item 18 & 0,304 & 0,361 & 0,361 \\
\hline Item 19 & 0,365 & 0,361 & \\
\hline Item 20 & 0,457 & & \\
\hline
\end{tabular}

Dari hasil olahan data SPSS versi 21, menunjukkan bahwa instrumen pernyataan pada tabel di atas tentang implementasi system informasi berbasis web dengan indikator-indikator pada setiap pernyataan yang memiliki nilai $r_{\text {hitung }}>r_{\text {tabel }}$ sesuai dengan persyaratan uji validitas bahwa nilai $r_{\text {hitung }}$ $>r_{\text {-tabel }}(0,30)$. Dengan demikian, dapat diketahui bahwa pernyataan-pernyataan diatas dinyatakan valid untuk digunakan sebagai alat ukur variabel karena semua pernyataan yang tertera di kuisioner memenuhi syarat.

\section{Uji Reliabilitas}

Uji reliabilitas (Kehandalan) merupakan ukuran kestabilan dan konsistensi responden dalam menjawab hal yang berkaitan dengan konstruk-konstruk pernyataan yang merupakan dimensi suatu variabel dan disusun dalam bentuk kuisioner. Maka pengertian realibilitas tes, berhubungan dengan masalah ketetapan hasil tes atau seandainya hasilnya berubah-ubah, maka dapat dikatakan tidak 
berarti. Reliabilitas suatu indikator atau kuesioner dapat diliihat dari nilai cronbach's alpha ( $\alpha$ ), dimana suatu konstruk atau indikator dikatakan reliabel yaitu apabila nilai cronbach's alpha (a) lebih besar (>) 0,60, maka indikator atau kuesioner adalah reliabel sedangkan apabila nilai cronbach's alpha (a) lebih kecil $(<)$ 0,60 maka indikator atau kuesioner tidak reliabel (Suswanto,2018). Secara keseluruhan uji reliabilitas dapat dilihat hasilnya pada tabel 5.29

Tabel 7. Hasil Uji Reliabilitas Kuesioner System Informasi Berbasis Web

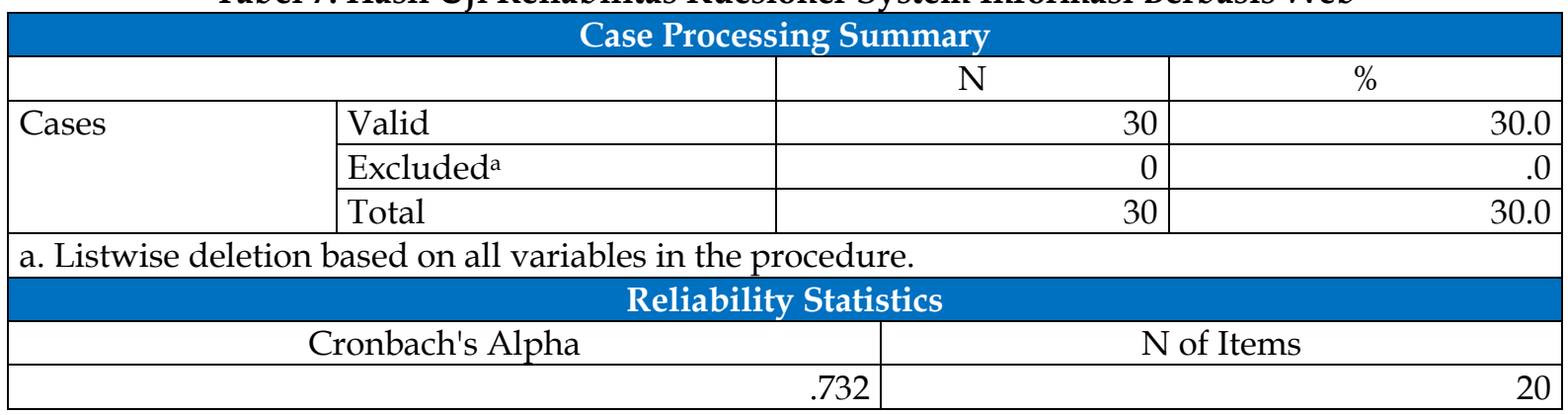

\section{A. Pembahasan}

Berdasarkan tujuan penelitian ini yakni untuk Merancang suatu system informasi pemasaran berbasis web yang dapat di akses oleh member dari PT. Affor Neo Jaya Makassar dimanapun dan kapanpun dengan leluasa. Setelah dilakukan uji coba penggunaan aplikasi Sistem Informasi Berbasis Web maka system pemasaran di perusahaan tersebut meningkat secara signifikan. Mereka dapat mengakses web perusahaan dimana saja, mereka dapat mengetahui jumlah produk yang tersedia ataupun produk yang telah habis. Mereka juga dapat melihat daftar harga produk untuk tiap item dan mereka dapat dengan leluasa menambahkan rekapan permintaan produk tanpa harus dating langsung ke kantor. Sebagaimana diketahui bahwa $(80,8 \%)$ member masuk kedalam kategori sangat setuju, $\left({ }^{\prime} 16,1 \%\right)$ member masuk ke kategori setuju dan hanya $(3,0 \%)$ member masuk ke kategori kurang setuju. Jadi dapat disimpulkan bahwa penerapan system informasi berbasis web pada system pemasaran telah mengalami peningkatan yang signifikan sehingga penggunaan system informasi berbasis web dinyatakan telah berhasil meningkatkan system pemasaran di PT. Affor Neo Jaya. Dengan demikian, maka hipotesis yang mengatakan bahwa implementasi system informasi berbasis web dapat memberikan informasi berupa laporan daftar harga dan informasi barang serta transaksi pembelian kepada konsumen pada aplikasi system informasi berbasis web di PT. Affor Neo Jaya dinyatakan telah berhasil di terapkan dan berhasil meningkatkan system pemasaran di perusahaan tersebut. Berdasarkan uraian yang telah dipaparkan sebelumnya, penulis menarik kesimpulan tentang Sistem Informasi berbasis web untuk meningkatkan system pemasaran pada PT. Affor Neo Jaya Makassar,bahwa:

1. Dengan pembangunan prototype sytem Insformasi berbasis web dapat memudahkan pembeli melakukan transaksi tanpa harus datang langsung ke kantor, dengan implementasi aplikasi berbasis web system pemasaran barang tersebut dapat dilakukan secara otomatis.

2. Aplikasi menyediakan fitur untuk pengelolaan daftar barang (katalog), barang masuk dan barang keluar secara terkomputerisasi, sehingga dapat mempercepat pengelolaan daftar barang secara otomatis dan tidak ada pencatatan ulang nota atau kuitansinya.

\section{Saran}

Adapun saran-saran yang ingin penulis berikan pada penelitian ini adalah sebagai berikut. (1) Untuk mengantisipasi adanya kerusakan sistem maupun perangkat keras, sebaiknya dalam jangka waktu tertentu dilakukan backup data. (2) Setelah aplikasi ini digunakan, sebaiknya dalam beberapa waktu ke depan data yang ada pada sistem dilengkapi, seperti template, artikel dan lain-lain. Agar meningkatkan kepuasan untuk penggunanya. 


\section{DAFTAR PUSTAKA}

A. Kadir, 1999. Konsep dan Tuntunan Praktis Basis Data, Yogyakarta: Andi,

Agus Saputra. 2012. Membuat Aplikasi Absensi dan Kuisioner untuk Panduan Skripsi. PT. Elex Media Koputindo. Jakarta

Aji.P.Ramadhan. 2008. Sistem Informasi Pemasaran Barang Ber basis Web pada Pamoro Jaya Tegal. Tegal.

Amstrong, Gary \& Philip, Kotler 1996 Dasar-dasar Pemasaran. Jilid 1, Alih Bahasa Alexander Sindoro dan Benyamin Molan, Prenhalindo, Jakarta.

Amaliah, Aqyunin. 2017. Implementasi Metode Prototype Dalam Membangun Aplikasi E-Business Berbasis Web pada toko usaha dagang di Bandung. Bandung.

Alexander, S. Agustinus. N, Shandy W. 2009. Implemensasi Sistem Informasi Pemasaran Dengan Teknologi Short Message Service Pada Tridjaya Jakarta Property. Universitas Kristen Petra. Yogyakarta

Atikah 2020 Perancangan system informasi penjualan berbasis web pada PT. Andalan Dharma Mulia Tangerang. Universitas Raharja. Tangerang

Chou, George Tsu-der. 1989. DBASE III. Erlangga: Jakarta.

Dewi Yuliana, 2017. Implementasi Sistem Informasi pada Perusahaan kosmetik Evieta. Jakarta.

Depkes RI. 1991. Pengumuman / Peraturan Pemerintah Wajib Daftar Alat Kesehatan, Kosmetika dan Perbekalan Kesehatan Rumah Tangga. Jakarta.

Fatur Rohman 2018 Implementasi system informasi berbasis web pada noni foto studio Jakarta. Universitas BSI Jakarta

Ghozali,Imam. 2011. Aplikas iAnalisis Multivariate dengan Program SPSS. Badan Penerbit Universitas Diponegoro, Semarang

Ghozali,. 2011. Aplikasi Analisis Multivariate Dengan Program SPSS. Cetakan Keempat. Semarang: Badan Penerbit Universitas Diponegoro.

Gulo, W. 2002. Metode Penelitian. Jakarta: PT. Grasindo

I. P. A. E. Pratama, 2015. E-Commerce, E-business, dan Mobile Commerce, Bandung: Informatika Bandung,

Irwin Nugroho 2011. System informasi penerimaan siswa baru berbasis web dengan PHP dan SQL. Universitas Negeri Yogyakarta. Yogyakarta.

Iyas 2011. implementasi system penjualan online berbasis E Commers pada usaha rumahan Griya Unik Wanita di Jakarta. Universitas Syarif Hidayatullah. Jakarta

Jonathan, Sarwono, 2006. Metode Penelitian Kuantitatif dan Kualitatif, Yogyakarta: Graha Ilmu,

Kotler, Philip, Keller L. Kevin, 2006, Marketing Management 12th edition. Upper Suddle River. New Jersey Prentice-hall. Inc

Kotler, Philip. 2006. Management Pemasaran. Salemba Empat. Jakarta.

Kristanto, Andri, 2008. Perancangan SIstem Informasi dan Aplikasinya, Yogyakarta: Gava Media,

Kusnadi, 2008. Sistem Operasi, Yogyakarta: Andi,

L. Fickel, 1999. Big Business, CIO Web Business,

M. Raymond, 2001. Metode Prototype, Jakarta: Prenhallindo,

Marsita Dewi 2004. Pembuatan Situs Web Almamater Perguruan Tinggi Menggunakan PHP Dan MySQL. Universitas Dipomegoro Semarang

McLeod Jr, Raymod dan George P Schell. 2008. Sistem Informasi Manajemen Edisi 10. Jakarta : Salemba Empat

Miles, MB. Dan AM. Huberman. 1992. Qualitative Data Analysis A Source book of New Method. SAGE. Baferly Hills.

Muhammad Zia'ulhaq 2014 Penerapan Sistem Informasi Berbasis Web untuk Mendukung Pengelolaan Administrasi di Promusic Recording Studio Jepara. Universitas Dian Nuswantoro Semarang

N Candra Apriyanto (2011) "System informasi penjualan arloji berbasis web pada CV. Sinar terang Semarang". Universitas Pembangunan Nasional "Veteran" Yogyakarta.

Nugroho, Adi, 2011. Perancangan dan Implementasi Basis Data, Yogyakarta: Andi,

Nugroho, Bunafit, 2009. Latihan membuat Aplikasi Web PHP dan MySQL dengan Dream weaver MX, Yogyakarta: Gava Media, 
Patricia E. Mountaines 2008. Pengembangan Aplikasi Berbasis Web Untuk Menampilkan Absensi Dan Nilai Akhir Peserta Didik (Studi Kasus Di SMP Negeri 32 Semarang).. Universitas Diponegoro Semarang

P. R. Kurnia, 2013. Customer Relationship Management, Jakarta: Ppm Manajemen,

Retno I.S. Tranggono. 1996. Kiat Apik Menjadi Sehat dan Cantik. Gramedia Pustaka Utama. Jakarta.

Raharjo,Suwanto. 2004, Teori, Analisa, dan Implementasi Jaringan Tanpa Disk ,pada GNU/Linux, Andi, Yogyakarta

Stanton, William J. 2003. Prinsip Pemasaran (terjemahan). Edisi 7, jilid 1. Erlangga. Jakarta.

Sugiono. 2011. Metode Penelitian Kualitatif Kuantitatif dan R\&D. Bandung.Alfabeta.

Siswanto Sastrohadiwiryo. 2018. Manajemen Tenaga Kerja Indonesia Pendekatan Administrasi dan Operasional. https://ejournal.unsrat.ac.id/index.php/emba/article/view/22362/22887

Seputar Pengetahuan, 2020. https://www.seputarpengetahuan.co.id/2020/09/implementasiadalah.html

S. Huff, 2000. Cases in Electronic E-commerce,

S. Kaplan, 2000. The New B2B Marketplaces,

Tribuana 2008. Penerapan teknologi system informasi berbasis web serta kajian sikap pengguna dengan pendekatan technology acceptance model (TAM) di bimbingan belajar BTA MAB Depok..Universitas Indonesia Depok

Wirtanto, 2004. Memahami Sistem Informasi, Bandung: Informatika, 